\title{
Impact of Tariffs and Nontariff Barriers on the International Trade
}

\author{
Ibragimova Naylya Muradovna, $\mathrm{PhD}$, \\ Head of Department \\ Institute of forecasting and macroeconomic research of the Republic of Uzbekistan, Uzbekistan
}

\begin{abstract}
In the modern world economy, tariff and non-tariff barrier regulation acts as an effective regulator, promoting greater openness of the market, or as the most widespread foreign trade instrument of protectionism. Over the past decades there has been a steady decline in the rates of import customs duties. On the other hand, non-tariff measures to regulate foreign trade are being applied more and more effectively. But at the same time customs and tariff policy continues to be a key factor determining the national trade regime and the conditions for access of foreign products to the domestic market. The main purpose of this research is to assess the influence of tariffs and non-tariff barriers on international trade, as these factors play an essential role in the international trade. The theoretical and methodological basis of the study was the work of scientists in the field of finance, state regulation of foreign economic activity and international relations. In the methodology part gravity model regression is assessed for tariff and non-tariff measures (NTMs) regulating foreign trade flows. As result, non-tariff barriers (NTMs) such as Sanitary and Phytosanitary Standards (SPS) and Technical Barriers to trade (TBT) have had the largest negative impact.
\end{abstract}

Keywords: International trade, tariff and nontariff barriers, Gravity model

JEL classification: A1, C01, C12, C31, C51, F21

\section{Introduction}

Over the past decades, international trade has affected the economic interests of individual segments of the population and entire countries, interests that are intertwined in the most complex manner and conflict with each other. This determines the need for a targeted impact of the government on trade relations with other countries through tariffs and non-tariff regulatory methods.

The general trend in the development of foreign trade policy is a weakening of protectionism and a promotion of liberalization, especially within the framework of integration associations. In recent years, the development of international trade has taken place in the context of accelerated liberalization; there is an increase in the impact of international and regional regulation, national regulation is weakening. But within the framework of foreign trade regulation, countries use trade policy instruments, in particular trade barriers, which are of an administrative and economic nature.

Protectionism is a policy aimed at protecting the domestic economy from foreign competition. Unlike the free trade policy, protectionism excludes the free operation of market forces, since it is assumed that the economic potential and competitiveness in the world market of individual countries are different, and therefore the free operation of market forces may be disadvantageous for less developed countries. Unlimited competition with the parties of stronger foreign states may lead to economic stagnation in the less developed countries and the formation of an inefficient economic structure for the country in question.

Trade barriers have a sufficient impact on the economies of countries. In general, studies show that the benefits of trade restrictions are more than offset by their costs, which are shifted to the shoulders of consumers. So, if we remove all the trade barriers in the world, then over 15 years, about 500 million people could be saved from poverty. Developing countries would receive hundreds of billions in annual income, at least half of which could be ensured by the removal of protectionism against their exports in industrialized countries. In addition, trade barriers contribute to the reduction of world production, and reduce the volume of international trade. The benefits that protected industries receive from the introduction of trade barriers are achieved at the cost of much greater losses for the economy as a whole. But since national production is necessary to preserve or re-establish the main structure-forming enterprises and industries without which it is impossible to have an effective economic mechanism, improve the structure of the economy, concentrate economic resources on promising areas of development, reduce the cost of some important goods, government pursues the goal of creating the most favorable conditions for the development of the national economy. 


\section{Literature Review}

Based on the theory of economics, there are two main reasons, why countries think that it is beneficial to take a part in the international trade: 1) differences in countries' comparative advantages that generate trade benefits over specialization, and 2) economies of scale, that can be yielded through the coordination of crossborder regulation and collaboration.

First benefit is conceded to the theory of comparative advantage by David Ricardo and the theory of absolute advantage by Adam Smith, both of them have demonstrated that trade's gain might be a positive-sum that all nations benefit. Henceforth, the theory assumes that trade is the gained positive sum where all countries benefit.

Second source of benefits can be brought by trading. The concept of economies of scale refers to the notion that production becomes more efficient as production volume grows. This typically happens in industries where fixed costs are large. Other reasons why economies of scale might be present include the fact that firms might be able to buy intermediary goods in bulk (and thus at a lower price), labor and capital specialization within the firm might be possible and labor expertise might increase efficiency in production after some time[18, $23]$.

For imposing of trade barriers, it can be said that there are many reasons. For example, some of them are social, other political or purely economic also to protect domestic consumers: by restricting imports or imposing safety standard and protecting health protection of domestic consumers (some goods such as foodstuffs and medical supplies are typical illustrations where these arguments can be applied). Trade restrictions, aimed for safety and protecting health are allowed on a regular basis in international trade regimes and this reasoning is considered legitimate.

To protect domestic production, governments regularly work to protect the internal producers from external competitors. The argument for this case is that domestic production of the country has positive externalities that multiplicatively benefit the wider economy (for example, overflows from development of domestic production on additional benefits in form of multiplicative domestic income and employment effects [16]. The argument is that, in order for these potential externalities to be realized, protection from international markets is necessary

Edward Leamer is the leading figure in the framework of the model of generalized proportions in the study of empirical problems about the impact of trade barriers. In a series of studies [19, 20] Leamer gives this issue a comprehensive theoretical basis for constructing empirical models suitable for estimating cross sections and the associated problems affected by the size of the data sets using specific econometrics to assess the impact of trade barriers. Leamer [20] evaluates the influences of trade barriers in order to find net trade flows.However, in empirical studies the influence of trade barriers on gross import is what ought to be under exploration [25].

A meta-analysis interprets the changes in evaluated trade effects of technical barriers in order to trade widely, by employing accessible estimates from experiential international trade literature, and accounting for showing the samples of information and methodology varieties. As a rule, agriculture and food industries are more obstructed with these obstacles than other sectors. Since tariffs had been reduced, non-tariff (NTBs) or non-tariff measures (NTMs) started being given more care and attention. Because of their internal heterogeneity, NTBs/NTMs are classified into several comparatively more homogeneous subgroups [14, 5, 15, 12].

Health and safety measures and technical standards, containing Sanitary and Phyto-Sanitary Measures (SPS), Technical Barriers to Trade (TBTs), and other standard-like policies are usually differentiated from other NTMs and their disputable effects on trade have been dissected broadly. Ganslandt andMarkusen [13] describe how both standards and technical controls have trading influence by increasing the costs of exporters and the same demand-strengthening effects by attesting quality and safety to costumers.

Experiential knowledge on technical measures has increased since the beginning of 1990's, particularly, it proliferated when research based on gravity equation had been made [10]. The literature demonstrates a broad range of estimated effects was derived from considerably impeding trade to significantly promoting trade.

Chevassus-Lozza et al. [4] discovered positive trade influence of sanitary measures and negative effect phytosanitary and quality measures. Disdier et al. [8, 7,9] demonstrated negative effects of TBTs and SPS on agricultural and food aggregate trade: 30 disaggregated industries were found at the HS2 aggregation level, while TBTs and SPS had positive impacts on 8 industries, negative effects on 12 industries, and insignificant effects on 10 industries. 
According to disaggregated findings of Nardella and Boccaletti[22], Fontagné et al. [12], and others the course and the significance of also reveal that the direction and the significance of the technical measures trade effects can be different among product groups and trade members. Overall, these facts of both trade-impeding and trade-strengthening lead to a confusion of technical measures for their patterns and cause a need in further Technical measures which contain TBTs, SPS and standard-like policies enclosed by MAST categories A through $\mathrm{C}$.

In addition to dissimilarities in the records, fluctuations in the trading outcomes possibly is produced by dissimilar procedures of practical procedures substitutions, concept individuality and extra differences of the methods. Some scientists practice the MRL to determine the usefulness of methodological procedures. MRL go in regression in numeral form, a direct and precise measurement of methodical procedures of interest [24, 26,27]. Nevertheless, usually methodical procedures are without straight dimensions in numbers, consequently there is necessity to create proxies. Usually the proxy functions of methodical procedures are counting variables, the ratio of frequencies, the ad valorem equivalent (ave) policies, dummy-variables. Selections amongst these dissimilar proxies can cause dissimilar approximations of trade effects of methodical procedures. Some academics strained to compare dissimilar proxies $[6,7,8]$, and the main stream of academics selected single proxy.

As the initial base for the calculations of gravitation [1], improvements in the description of the calculations of gravitation carried a lot of variants and modifications. As in a representative tax system method, which is used to calculate the amount of tax payments collected in the region [17], this method avoids the direct use of an import tax base indicator and uses a reasonable measure of economic capacity such as GDP volume. Experimental science works in diverse degrees correspond to diverse theoretic grounds, and they can cause fluctuations in the anticipated influence of methodical procedures on trade.

According to a simplest and early formulation of gravity equation the trade capacity between two countries is proportional to the product of the countries GDPs and the distance between these two states. It usually comes in a diminished form:

$$
\log X i j=\alpha+\alpha \log (Y i)+\alpha \log (Y j)+\alpha 3 H i j+\varepsilon i j,(1)
$$

where $X i j$ is the value of trade from country $i$ to country $j, Y_{i}$ and $Y_{j}$ are the Gross Domestic Product (GDP) of country $i$ and country $j$.GDP is a proxy for production volume in the exporting state, which at a sectoral level could serve as the supply of the exporter for that sector. GDP of the importing country is stimulated by demand considerations of are presentative consumer. The variables $H_{i j}$ describe distance between trade partners.

Some scientists present previous writings on methodical procedures and related procedures to evaluate this policy and its consequences [5, 2, 21]. Previously, the usual approaches yet dominate nowadays, nonetheless through noteworthy progress. An advanced concept of fundamental gravity calculations and econometric approximation methods, considering novel challenges, is handling of zero-trade currents [11]. Furthermore, recently academics lean towards to studying the impact of methodical procedures through disaggregated numbers $\&$ broader analysis of regions and policy instruments.

\section{Methodology \\ 3.1. Model}

In order to estimate the impact of trade barriers on trade, the gravity model was used. This model is widely used to identify potential trade flows in order to assess the impact on trade monetary agreement, ethnic ties, customs unions, linguistic identification, exchange rate mechanism and international borders.

At present, in this model the basic expression is formulated as following: the trade flow from one country to another country is marked by the trade flow of country $\mathrm{i}$ to another country $\mathrm{j}\left(\mathrm{X}_{\mathrm{ij}}\right)$ is proportional to the product of GDP of the two countries $\left(\mathrm{GDP}_{\mathrm{i}}, \mathrm{GDP}_{\mathrm{j}}\right)$ and also inversely relational to thedistance between countries is marked by the $\mathrm{D}_{\mathrm{ij}}$, and in a broad sense includes other factors that can create resistance to trade:

$$
X_{i j}=\frac{G D P_{j}^{\alpha_{2}} G D P_{i}^{\alpha_{3}}}{D_{i j}^{\alpha_{3}} * \text { Tarif } * N T M}
$$

where: $X_{i j}$ - imports of “j” from “i” + Export from “i”" to “ $j$ ”, GDPi - factors of Exporter, GDPj - factors of Importer, $\mathrm{D}_{\mathrm{ij}}$ - distance, Tariff - tariff duties used/exporter's trade barriers “i”" to enter / reaching market “ $\mathrm{j}$ ”, NTM - non tariff measures. 


\subsection{The CEPII database on Tariffs (MACMAP-HS6)}

"The CEPII gravity dataset" used in this research provides square gravity dataset across the globe [3]. Originally, this dataset was generated by Thierry Mayer and Keith Head and all data are taken for the period from 1999 to 2006.

Market Access Map (MAcMap) makes available an exhaustive, disaggregated and bilateral measurement of used tariff duties. It takes into account trade preferences and regional agreements systematically. The source figures were taken from ITC (WTO - UNCTAD). These sets of data are made for analytical aims and affords equivalent of an ad valorem percentage used for protection of each triplet (product- importer-exporter) for the period of 2001, 2004 and 2007.

Additionally, MAcMap-HS6 is the source of information which applied for tariffs in the dataset of GTAP. This methodology is considered to be complementary to the three statements (2001, 2004 and 2007). To mineralize the problems of endogeneity when aggregating data or calculating unit costs, it is based on the conception of "reference groups of countries": the values of bilateral trade and bilateral units are replaced by a reference group of countries (import side for the weighing scheme, export for unit cost).

The MAcMap-HS-6 database, which provides a consistent equivalent ad valorem measure of quotas and tariff duties, rates for 163 states and 208 associates at the six-digit level of the Harmonized System, taking into account all preferential contracts of 5111 products. The Harmonized System (HS) is a worldwide classification form which was constructed for the classification of products. For participating countries it allows to classify the goods sold on a common basis for customs determinations. The methodology described is used to calculate the ad valorem equivalent of theoretical protection. Particular attention is paid to minimize the displacement of the initial combination in the procedure, while recognizing the structural differences in the specialization of exports.

\subsection{The CEPII database on Non-tariff measures}

The CEPII database NTM-MAP (MAP measures) contains indicators from UNCTAD TRAINS databases as input data and measures the frequency of non-tariff measures using different methodologies.

For the emergence of NTM, as a proxy three indexes are proposed: frequency index, prevalence and coverage factor. These indices are computed systematically for 71 countries (and EU28) globally and for combine two production levels (HS2 or HS-Section) for various five categories, such as NTM (Sanitary and Phytosanitary Standards (SPS);Technical Barriers to trade (TBT); Pre-shipment inspection (PSI); (D) unforeseen trade protection measures; and (E) non-automatic quotas, prohibitions, licensing and quantitative control measures).

In the NTM-MAP Country database there are available variables that specify the importing nation. The data collection:

- Num: stands for the frequency score of different NTMs and NTMs' 5 sub-categories

- Pres: the volume of products with as a minimum of one NTM and one of NTMs' 5 sub-categories

- Freq: the frequency factor of different NTMs and NTMs' 5 sub-categories

- Cov: the coverage ratio of different NTMs and NTMs' 5 sub-categories

\subsection{Estimation Results}

The regressions were estimated for tariffs and non-tariff barriers, using the CEPII dataset for the period from 1999 to 2006 by the help of gravity model (table 1 below and in the appendix).According to the table 1, if origin country's GDP increases by $1 \%$ then the trade volume will increase by $1.279 \%$. Moreover, when GDP of domestic countries grows by $1 \%$ the trade volume accordingly increases by $1.024 \%$. Respectively, for the GDPs of origin and domestic countries, the error of coefficient estimation close to 0.000 which indicates to the exact result of estimation. 
Table 1. Effect of Mean Tariff and all Nontariff Barriers on Trade(Export + Import)

\begin{tabular}{|l|c|c|c|c|}
\hline Flow of trade (Lflow) & Coef. & $\mathrm{P}>|\mathrm{z}|$ & \multicolumn{2}{|c|}{$[95 \%$ Conf. Interval] } \\
\hline GDP of origin country (lgdp_o) & 1.2791 & 0.000 & 1.243 & 1.314 \\
GDP of domestic country(lgdp_d) & 1.0241 & 0.000 & .951 & 1.097 \\
Population of origin country(lpop_o) & - & 0.379 & -.060 & .0230 \\
Population of domestic country (lpop_d) & 0.01880 .0824 & 0.052 & -.0005 & .1655 \\
Distance (ldistcap) & -0.9459 & 0.000 & -1.021 & -.871 \\
Borders (border) & 0.7744 & 0.000 & .369 & 1.179 \\
Common Language (comlang_off) & 1.0223 & 0.000 & .851 & 1.193 \\
\hline Tariffs average (tariff_avg) & $\underline{\mathbf{- . 0 1 4 1}}$ & 0.047 & -.028 & -.00017 \\
\hline Non Tariff Barriers average(f_ntb_al_avg) & $\underline{\mathbf{- 2 . 9 8 6 9}}$ & -0.000 & -3.442 & -2.5318 \\
\hline
\end{tabular}

Next, with the growth of the population in country of origin, the volume of trade is decreasingby -0.0188 . However, the destination country indicators showed a positive ratio that led to 0.0824.Based on this estimation, when the distance of two partners increase by 1 unit (km, miles) the trade flow falls to the -0.9459 . The influence of tariffs also reduced the indicators of volume of trade, as it shown by tariffs, tariffs negatively affect trade volume coefficient $-0.014 \%$. In addition, the increasing of Non-Tariff barriers by 1unit, will affect on the decreasing of trade volume by -2.986 .

The second regression (table 2) additionally estimates impact of the non-tariff barriers of five categories, such as Sanitary and Phytosanitary Standards (SPS), Technical Barriers to trade (TBT); Pre-shipment inspection (PSI); (D) unforeseen trade protection measures and (E) non-automatic quotas, prohibitions, licensing and quantitative control measures.

Table 2. Tariff and 5 different types of Nontariff Barriers

\begin{tabular}{|l|c|c|c|c|}
\hline Flow of trade (Lflow) & Coef. & P>|z| & \multicolumn{2}{|c|}{$[95 \%$ Conf. Interval] } \\
\hline GDP of origin country (lgdp_o) & 1.2831 & 0.000 & 1.2477 & 1.3186 \\
GDP of domestic country (lgdp_d) & 1.0136 & 0.000 & .93646 & 1.0908 \\
Population of origin country (lpop_o) & -0.0155 & 0.470 & -.05746 & .0265 \\
Population of domestic country (lpop_d) & 0.1024 & 0.019 & .01649 & .1883 \\
Distance (ldistcap) & -0.9623 & 0.000 & -1.0375 & -.8870 \\
Borders (border) & 0.7495 & 0.000 & .3443 & 1.1548 \\
Common Language (comlang_off) & 1.0109 & 0.000 & .8400 & 1.1818 \\
\hline Tariffs average (tariff_avg) & $\underline{\mathbf{. 0 1 5 0 9}}$ & 0.042 & -.0297 & -.00055 \\
\hline Non Tariff Barriers: & & & & \\
SPS (f_ntb_1_avg) & $\underline{\mathbf{- 2 2 1 . 7 8 6}}$ & 0.105 & -489.6659 & 46.0927 \\
TBT (f_ntb_2_avg) & $\underline{\mathbf{- 1 5 . 3 1 0 3}}$ & 0.002 & -489.6659 & 46.0927 \\
PSI (f_ntb_3_avg) & $\underline{\mathbf{- 3 . 7 3 5}}$ & 0.000 & -5.2447 & -2.2247 \\
UTP(f_ntb_4_avg) & $\underline{\mathbf{- 2 . 0 3 1}}$ & 0.000 & -2.6083 & -1.4539 \\
NAQ (f_ntb_5_avg LQ) & $\underline{\mathbf{3 0 4 . 9 0 9}}$ & 0.261 & -970.0338 & 3579.852 \\
\hline
\end{tabular}

Looking at the results of estimation of the regression for Non-Tariff Barriers, it can be seen that with growth of GDP of origin country by 1 percent, the trade volume rises in whole by $1.283 \%$.On the other side domestic country GDP growth results in the trade volume by $1.013 \%$.Next, when the rate of population has risen, it influences on origin country's trade volume negatively, which is -0.015; whereaspopulation growth in domestic country, vice versa, has showed positive impact on trade, which is 0.1024 . As mentioned in the previous analysis of the table 1, because of high level of distance between two partners, the trade volume decreases as indicated by the coefficient estimation of -0.9623 . Of course, tariffs also showed the little negative influence on the trade volume with the number -0.0150 . 
But the largest negative impact assessed for SPS non-tariff barriers. With increase of the Sanitary and Phytosanitary Standards for one unit, the trade volume has dramatically dropped by the $-221.78 \%$. Second, a lower but still large negative effect impact is estimated for TBT non-tariff barriers, technical barriers to trade is $15.31 \%$.Besides, Pre-shipment inspection and Unforeseen trade protection measures distort trade volume by$3.734 \%$ and -2.0311 ,respectively.

\section{Conclusion}

All developed countries use various trade barriers to protect the domestic market. However, use of trade barriers and protectionism bears the worst consequences and huge costs and losses for society. But still there are arguments in defense of protectionism like national security, protection of the national industry, life and health of the population, the environment, and acceleration of the competitive advantages of importing countries. Therefore, countries by any means tend to create conditions primarily for the development of national economies. There are also political motives that sometimes completely disagree with the goals of free trade. As a result, it turns out because of those political realities there is often a greater increase in tariff and non-tariff barriers than this could be justified by social well-being.

The main objective of this research was to investigate the impact of tariffs and non-tariff measures on international trade. Thus, the essence of trade barriers and the regulation of foreign trade expressed in the form of imposing duties, non-tariff barriers, import quotas, and so on are shown.

Based on the results of quantitative research, assessment of Tariffs and NTBs is made on the total volume of International trade. In order to estimate the influence of tariffs and non-tariff measures on international trade there have been used a gravity model. This model is helped to identify potential trade flows in order to assess the impact on trade monetary agreement, ethnic ties, customs unions, linguistic identification, exchange rate mechanism and international borders.

Two regressions based on the gravity model were estimated for tariffs and total frequency of all non-tariff barriers, and separately for five categories of non-tariff barriers, such as Sanitary and Phytosanitary Standards (SPS), Technical Barriers to trade (TBT); Pre-shipment inspection (PSI), unforeseen trade protection measures and non-automatic quotas, prohibitions, licensing and quantitative control measures. The CEPII dataset for the period from 1999 to 2006 is used.

Results of assessment of the regression allowed to show how tariffs and non-tariff barriers affect the trade volume. Non-tariff barriers (NTMs) such as Sanitary and Phytosanitary Standards (SPS) and Technical Barriers to trade (TBT) have had the largest negative impact.

\section{References}

[1] Anderson, J. E. 1979. "A Theoretical Foundation for the Gravity Equation," American Economic Review 69(1): 106-16.

[2] Beghin, J. C., and Bureau, J.C. 2001. "Quantitative Policy Analysis of Sanitary, Phytosanitary and Technical Barriers to Trade," Economie Internationale issue 3(no 87): 107-130.

[3] CEPII - Gravity - Presentation. 2017. CEPII - Gravity - Presentation. [ONLINE] Available at: http://www.cepii.fr/CEPII/en/bdd_modele/presentation.asp?id=8.

[4] Chevassus-Lozza, E., Latouche, K., Majkovic, D., and Unguru, M. 2008. "The Importance of EU-15 Borders for CEECs Agri-food Exports: The Role of Tariffs and Non-tariff Measures in the Pre-accession Period”. Food Policy 33(6): 595-606.

[5] Deardorff, A., and Stern, R. 1998. The Measurement of Non-Tariff Barriers. OECD Economics Department Working Papers No. 179, OECD Paris.

[6] Disdier, A.-C., Fekadu, B., Murillo, C., and Wong, S.A. 2008a. "Trade Effects of SPS and TBT measures on Tropical Products," ICTSD Issue Paper \# 12.

[7] Disdier, A.-C., and Fontagné, L. 2008b. "Trade Impact of European Measures on GMOs Condemned by the WTO Panel," 2008 International Congress, August 26-29, Ghent, Belgium 44392, European Association of Agricultural Economists.

[8] Disdier, A.-C., Fontagné, L., and Mimouni, M. 2008. "The Impact of Regulations on Agricultural Trade: Evidence from the SPS and TBT Agreements," American Journal of Agricultural Economics 90(2): 336-350. 
[9] Disdier, A.-C., and Marette, S. 2010. "The Combination of Gravity and Welfare Approaches for Evaluating Non-tariff Measures," American Journal of Agricultural Economics 92(3): 713-726.

[10] Evenett, S.J., and Keller, W. 2002. "On Theories Explaining the Success of the Gravity Equation," Journal of Political Economy vol. 110(2): 281-316.

[11] Feenstra, R. 2004. Advanced International Trade, Princeton, N.J.: Princeton University Press. Fontagné, L., Mimouni, M., and Pasteels J.M. 2005. "Estimating the Impact of Environmental SPS and TBT on International Trade," Integration and Trade 22: 7-37.

[12] Fontagné, L., Mayer, T., and Zignago, S. 2005. "Trade in the Triad: How Easy is the Access to Large Markets?" Canadian Journal of Economics 38(4): 1401-1430.

[13] Ganslandt, M. and Markusen, J. R. 2001. "Standards and Related Regulations in International Trade: A Modeling Approach," NBER Working Papers 8346.

[14] Harrigan, J. 1993 "OECD Imports and Trade Barriers in 1983," Journal of International Economics 34(1-2): 91-111.

[15] Haveman, J. D., Nair-Reichert, U., and Thursby, J.G. 2003. "How Effective are Trade Barriers? An Empirical Analysis of Trade Reduction, Diversion, and Compression," The Review of Economics and Statistics 85(2): 480-485.

[16] Ibragimova N (2016) Modeling Household Income and Consumption Expenditure Multipliers for Uzbekistan Based on SAM. Int J Econ Manag Sci 5: 375. doi: 10.4172/2162-6359.1000375

[17] Ibragimova N (2016b) Econometric Analysis of Regional Tax Capacity for Uzbekistan. Int J Econ Manag Sci 5: 384 doi: $10.4172 / 2162-6359.1000384$

[18] Kotey, Richard, Foreign Direct Investment and Spillover Effects in Africa: An Empirical Review (May 7, 2019). International Journal of Science and Management Studies (IJSMS), 2019, Available at SSRN: https://ssrn.com/abstract=3384231

[19] Leamer, Edward E, 1974. "The Commodity Composition of International Trade in Manufactures: An Empirical Analysis," Oxford Economic Papers, Oxford University Press, vol. 26(3), pages 350-374, November.

[20] Leamer, Edward, (1990), Latin America as a target of trade barriers erected by the major developed countries in 1983, Journal of Development Economics, 32, issue 2, p. 337-368.

[21] Maskus, K. E., Wilson, J. S., and Otsuki, T. 2000. "Quantifying the impact of technical barriers to trade: a framework for analysis," Policy Research Working Paper Series 2512, The World Bank.

[22] Nardella, M., and Boccaletti, S. 2004. "The Impact of EU And US Agro-Food Non Tariff Measures On Exports From Developing Countries," 2004 Annual meeting, August 1-4, Denver, CO, American Agricultural Economics Association.

[23] Okoro, C.O., Nzotta, S. N., Alajekwu, U. B., Effect of International Capital Inflows on Economic Growth of Nigeria (2019). International Journal of Science and Management Studies (IJSMS), 2019, Volume: 02 Issue: 01 January to February 2019

[24] Otsuki, T., Wilson, J.S., and Sewadeh, M. 2001a. "What price precaution? European harmonization of aflatoxin regulations and African groundnut exports," European Review of Agricultural Economics 28(2): 263-283.

[25] Qing Wang, December 1, 2001, Import-Reducing Effect of Trade Barriers : A Cross-Country Investigation. 2001. Import-Reducing Effect of Trade Barriers : A Cross-Country Investigation. [ONLINE] Available at: http://www.imf.org/external/pubs/cat/longres.aspx?sk=15553.0.

[26] Wilson, J. S., and Otsuki, T. 2001. "Global trade and food safety - winners and losers in a fragmented system," Policy Research Working Paper Series 2689, The World Bank.

[27] Wilson, JS, Otsuki, T., and Majumdsar, B. 2003. "Balancing food safety and risk: do drug residue limits affect international trade in beef?" Journal of International Trade \&Economic Development 12(4): 377-402. 


\section{Appendix}

Table 1. Effect of Mean Tariff and all Nontariff Barriers on Trade

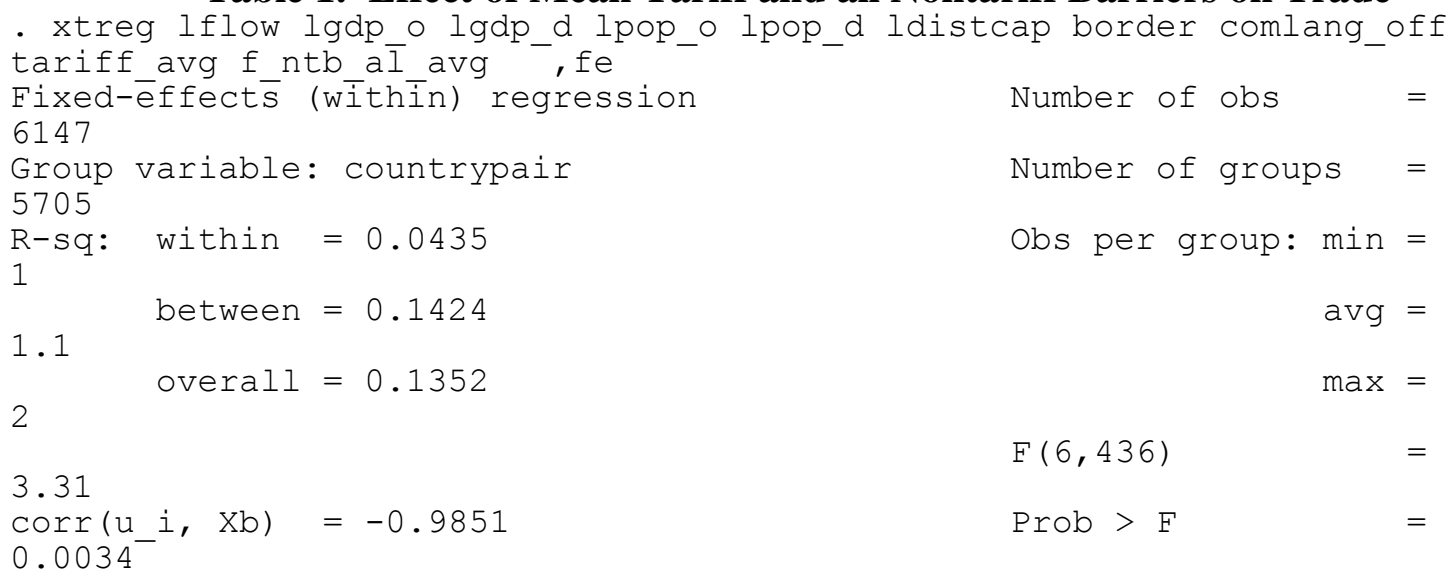

Table 2. Tariff and 5 different types of Nontariff Barriers

- xtreg lflow lgdp_o lgdp_d lpop_o lpop d ldistcap border comlang_off

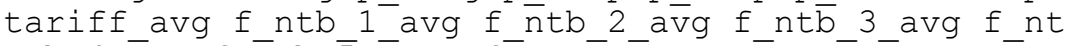
$>\mathrm{b} 4 \overline{\mathrm{a}} \mathrm{vg} \mathrm{f} \overline{\mathrm{n}} \mathrm{tb} \overline{\mathrm{s}} \overline{\mathrm{a}} \mathrm{vg}, \mathrm{f} \overline{\mathrm{e}}$

Fixed-effects (within) regression

6147

Group variable: countrypair

5705

R-sq: within $=0.0604$

Number of obs

Number of groups $=$

1

Obs per group: $\min =$ 


$\begin{array}{lll}1.1 & \text { between }=0.0000 & \operatorname{avg}= \\ 2 & \text { overall }=0.0002 & \text { max }= \\ 3.09 & \text { F }(9,433) & = \\ \text { Corr }(\mathrm{u} i, \mathrm{Xb})=-0.9983 & \text { Prob }>\mathrm{F} & = \\ 0.0013 & & \end{array}$

Interval]

lflow | Coef. Std. Err. $t \quad P>|t| \quad$ [95\% Conf.

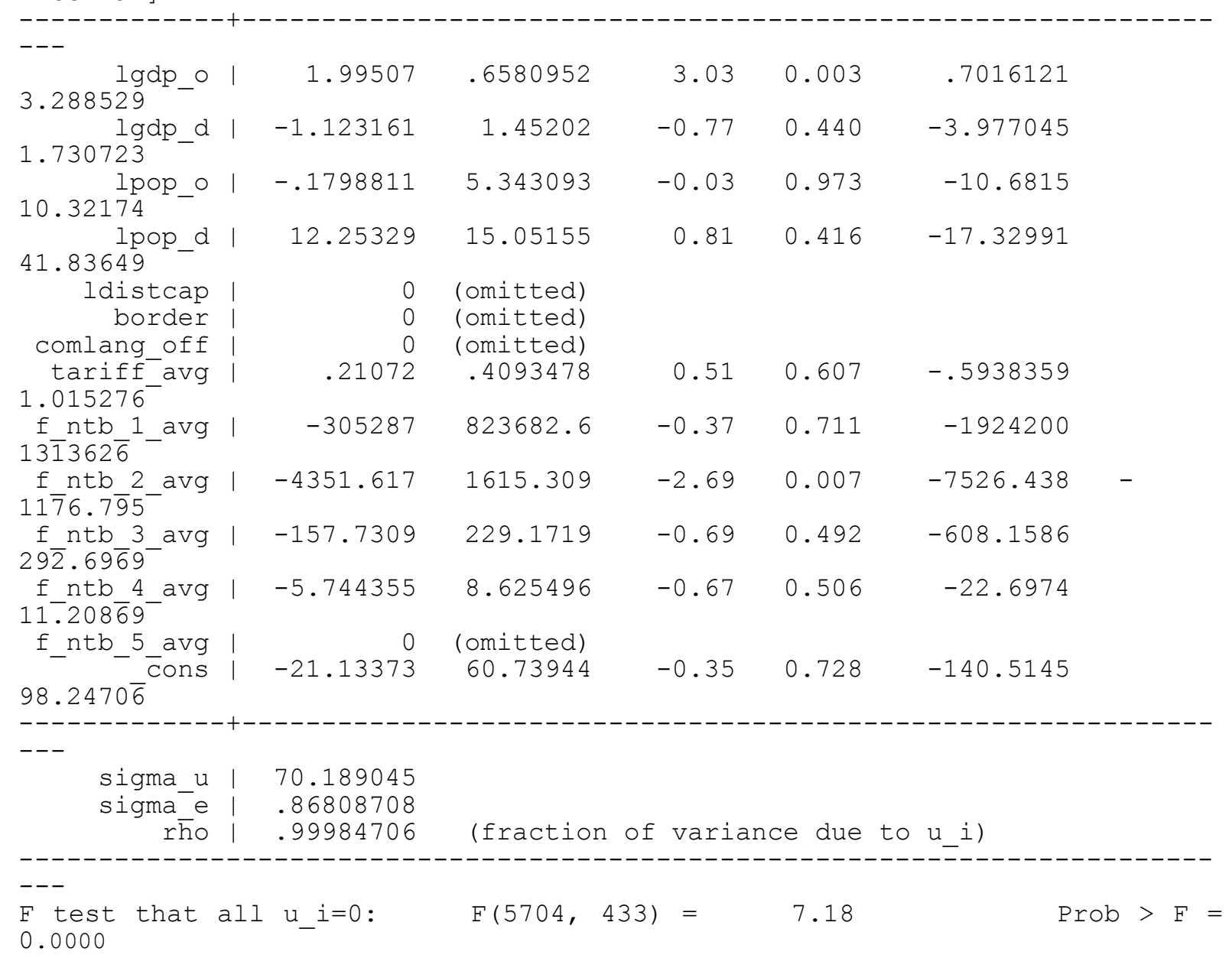

